\title{
Comprehensive Approach of Modeling and Simulation of Solar Photovoltaic Power Plant
}

\author{
Gururaj*, Anguraja.R**, Dr.R.Prakash ${ }^{* * *}$ Dr.H.Naganagouda**** \\ "(Department of Electrical and Electronics Engineering, PG Scholar, Don BoscoInstitute of Technology, \\ Bengaluru, Karnataka, India. \\ ** (Associate Professor and Head of the Department of Electrical and Electronics Engineering,Don \\ BoscoInstitute of Technology, Bengaluru,Karnataka, India. \\ ${ }^{* * *}$ (Professor \& Principal, Department of Electrical and Electronics Engineering, Don Bosco Institute of \\ Technology, Bengaluru, Karnataka, India. \\ ***** (Director, National Training Centre for Solar Technology, Karnataka Power Corporation \\ LimitedBengaluru,Karnataka,India. E-mail:hnaganagouda@gmail.com)
}

\begin{abstract}
The growing energy demand in developing nations has triggered the issue of energy security. This hasmade essential to utilize the potential of renewable resources. Grid connected PV systemsis the best alternatives in renewable energy at large scale. Analysis of these gridconnected plants could help in designing, operating and maintenance of new grid connected systems. The objective of this paper is to model the design and simulation of grid connected 10MW solarphotovoltaicpower plant by using the specifications of equipment's provided based on the availability of the component in Shivanasamudram,Karnataka,India. The PV generation system behaves well in different conditions of solar radiance and temperature of PV panels, preserving its stability and succeeding in extracting the maximum power from the PV panels by MPPT technique.
\end{abstract}

Keywords: Grid-connected PV plant, MPPT,Photovoltaic, Solar Power Plant, Solar cell, Semiconductor material.

\section{INTRODUCTION}

Increasing demand and scarcity in conventional sources have triggered the scientist for the development of research in the field of renewable energy sources especially solar energy. India has tremendous scope of generating solar energy. The reason being the geographical location and it receives solar radiation almost throughout the year, which amounts to $3000 \mathrm{~h}$ of sunshine. This is equal to more than 5000 trillion $\mathrm{kWh}$. Almost all parts of India receive 4-7 $\mathrm{kWh}$ of solar radiation per sq meters[1].Solar cells are made of semiconductor materials, such as silicon.Photovoltaicsystems are comprised of photovoltaic cells, devices that convert light energy directly into electricity [2].The solar power where sun hits atmosphere is $1017 \mathrm{~W}$. The solar power on the surface of earth is $1016 \mathrm{~W}$. The total worldwide power demand of all needs of civilization is $1013 \mathrm{~W}$. Therefore, the sun gives us 1000 times more power than we need. If we can use $5 \%$ of this energy, it will be 50 times what the world will require [3].The ever increasing energy consumption, the soaring cost and the exhaustible nature of fossil fuel, and the worsening global environment have created increased interest in green power generation systems[4].The amount of energy generated from PV power has a greater importance in the energy generation. With the increase of renewable penetration, the grid support provided by these sources is fundamental. As a result, new grid are appearing or being updated, forcing PV power plants to provide grid support [5].In one day, it provides more energy than our current population would consume in 27 years. In fact, "The amountof solar radiation striking the earth over a three-day period isequivalent to the energy stored in all fossil energy sources.

The operation of a photovoltaic (PV) cell requires 3 basicattributes:

1. The absorption of light, generating either electronholepairs or exactions.

2. The separation of charge carriers of opposite types. 3. The separate extraction of those carriers to an externalCircuit[6].

This technology requires little maintenance but it needs a good implementation of the DC-DC or/and DC-AC converters to obtain high efficiencies. There are lots of researches made in the field of photovoltaic conversion and propose new converters, among them a SEPIC converter is designed [7].A photovoltaic array is made with combined series/parallel combinations of pv solar modules which are composed of combination of pv cells usually assembled in series [8].This will be a very good way toboost the existing electricity production 
capacity inthecountry, which is mainly from hydro and thermalsources. This will contribute positively to theworsening energy situation in the country. Solarenergy, being a renewable source, will also provideenergy without pollutants and greenhouse gasemissions. This can go a long way to help mitigate theadverse effect of global warming as well as contributeto sustainable energy development[9].

To the best of author's knowledge, minimal work is dealt with the design and simulation of grid connected 10MW solar photovoltaic plant by using the specifications of equipment are provided based on the availability of the component in plant. The present work concentrates to get an optimization of the power supplied to the network, depending on the irradiance intensity of the sun.

\section{CIRCUIT MODELLING OF SOLAR CELL}

A solar cell is the building block of a solar panel. A photovoltaic module is formed by connecting many solarcells in series and parallel. Considering only a single solar cell; it can be modeled by utilizing a current source, a diodeand two resistors. This model is known as a single diode model of solar cell. Two diode models are also available butonly single diode model is considered here

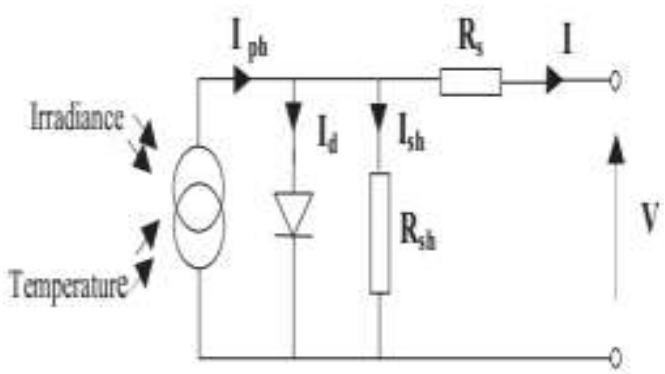

Fig.1Equivalent circuit of photovoltaic cell

General mathematical description of I-V output characteristics for a PV cell has shown below. The PV cell is usually represented by the single diode model. The single diodeequivalent circuit of a solar cell is shown in Figure 1.The I-V characteristics equation of solar cell is given asfollows:

The basic equation that describes the I-V curve characteristic of the photovoltaic model is as follows:

$$
I=I_{p h}-I_{s} \cdot\left[\exp \left(\frac{q\left(V+R_{s} I\right)}{n k T}\right)-1\right]-\frac{V+R_{s} I}{R_{s h}}
$$

Where:

I: cell current $(\mathrm{A})$.

Iph: light generated current (A).

Is: diode saturation current $(\mathrm{A})$.

$\mathrm{q}$ : charge of electron $=1.6 \times 10-19($ Coulomb $)$.

$\mathrm{V}$ : cell output voltage $(\mathrm{V})$.
Rs: series resistor (fi)

K: Boltzmann constant $=1.380662 \times 10-23(\mathrm{j} / \mathrm{K})$.

$\mathrm{T}$ : cell temperature $(\mathrm{K})$.

Rsh: shunt resistor (fi).

For a given irradiance and temperature, the photovoltaic call based on silicon has a nonlinear I-V characteristic as it is shown in Fig.2.

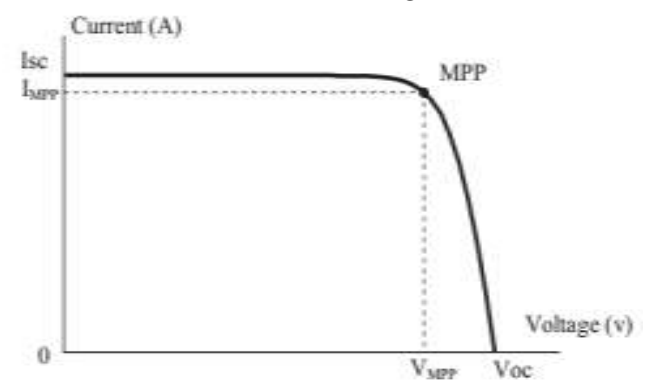

Fig.2Characteristic of I-V curve of photovoltaic cell Where: for a given temperature and irradiance

Isc: short circuit current (A).

IMPP: current when power is $\max (\mathrm{A})$.

Voc: open circuit voltage (V).

VMPP: voltage when power is $\max (\mathrm{V})$.

\section{TYPES OF SOLAR PHOTOVOLTAIC POWER SYSTEM}

The PV systems are designed to supply power to electrical loads. The load may be of DC or AC type and depending on the application, the load may require power during the daytime only or during the night time only or even for 24 hours a day. Since a PV panel generates power only during sunshine hours, some energy storage arrangement is required to power the load during the non-sunshine hours. This energy storage is usually accomplished through batteries. During the non-shine hours the load may also be powered by auxiliary power sources such as diesel generator, wind generator or by connecting the PV system to the grid or some combination of these auxiliary sources as shown in fig. 3. Here preferring grid connected solar PV system only PV systems can be broadly divided into the following categories as shown in fig 3 .

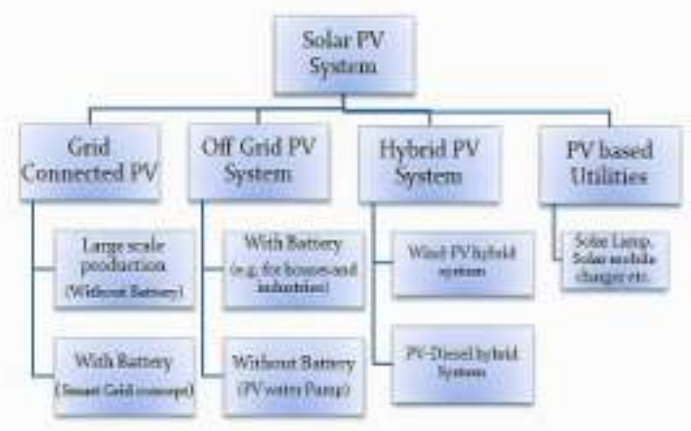

Fig.3Classification of photovoltaic system 


\section{DESIGN OF THE PV POWER GENERATION SYSTEM}

The design of a PV power generation system, with aninstalled power of $10 \mathrm{MW}$, is proposed as follows.

1) A PV array of panelsstrin`gs such as to obtain a maximum power of $10 \mathrm{MW}$;

2) A SEPICconverter used as a load regulator andrespectively to convert the output voltage of the PV array to asuitable voltage for the inverter;

3) Inverter to exportthe electrical energy to the three-phase grid;

4) A three-phase step-up transformer to adapt thelowvoltage output of the inverter to the grid;

5) The PV power generation system controller, whichcontains the MPPT controller for the SEPIC converterand the inverter's controller.

The MPPT controller is used to control the duty cycle inorder to maintain the operating point as close as possible tothe maximum power point of the PV array.

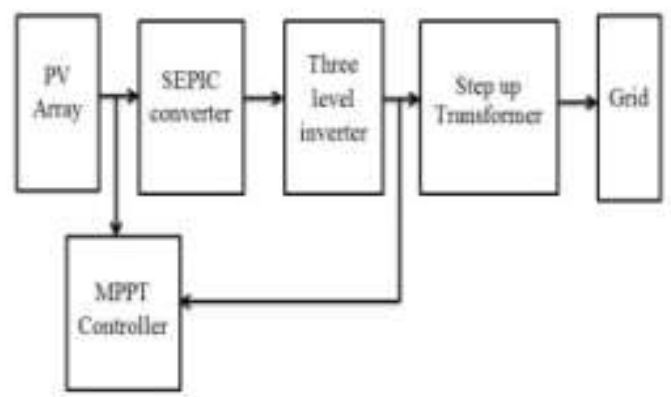

Fig.4Block Diagram of PV Power Generation System.

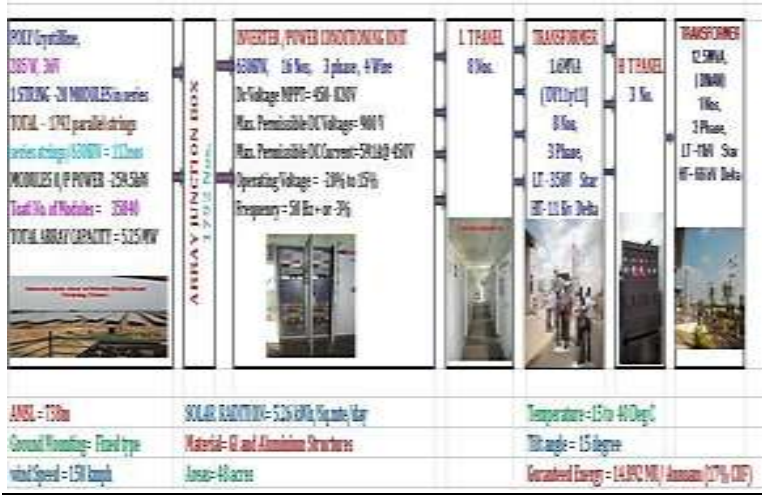

Fig.5Technical specification details of Solar PV power plant

\begin{tabular}{|l|l|l|l|l|l|}
\hline $\begin{array}{l}\text { Sl } \\
\text { no }\end{array}$ & $\begin{array}{l}\text { Dat } \\
\text { e }\end{array}$ & $\begin{array}{l}\text { Generation/ } \\
\text { export of } \\
\text { power to the } \\
\text { power }\end{array}$ & $\begin{array}{l}\text { Real- } \\
\text { time } \\
\text { Results }\end{array}$ & $\begin{array}{l}\text { Simulati } \\
\text { on } \\
\text { Results }\end{array}$ \\
\cline { 6 - 6 } & & $\begin{array}{l}\text { Start } \\
\text { Time( } \\
\text { AM) }\end{array}$ & $\begin{array}{l}\text { End } \\
\text { Timer } \\
\text { PM) }\end{array}$ & $\begin{array}{l}\text { Daytota } \\
\text { 1 } \\
\text { generati } \\
\text { on in } \\
\text { kwh }\end{array}$ & $\begin{array}{l}\text { Daytota } \\
\text { generati } \\
\text { on in } \\
\text { kwh }\end{array}$ \\
\hline 01 & $\begin{array}{l}01- \\
\text { Jan }\end{array}$ & $06: 40$ & $05: 50$ & 50240 & 54000 \\
\hline
\end{tabular}

\section{SIMULATION OF SOLAR POWER} PLANT

By using the designing parameters of the PV grid given above and a simulation ofa field with PV cellswas done in theSimulink module which belongstoMATLAB.The Simulink model of the PV field is built by usingElements from the library SimPowerSystems. The model of PV field includes the configuration of thenumber of PV cells in series and in parallel.The control system MPPT allows for a maximal energyrecovering, irrespective to temperature and illumination. The control system MPPT allows for a maximal energyrecovering, irrespective to temperature and illumination. ThevoltageVPV and the current IPV are continuously measured in order to deduce the power extracted from the panel.The control of the three-phase inverter is performed such as to export the power provided by the PV field in the ACnetwork of and to preserve a constant voltage of at the output terminals. The model of the network in which the PV generating system exports power includes a MV load, stepupTransformer's, models for long lines and connected by using a step-up transformer.Below figure shows the simulation modelof $10 \mathrm{MW}$ solar power plant.

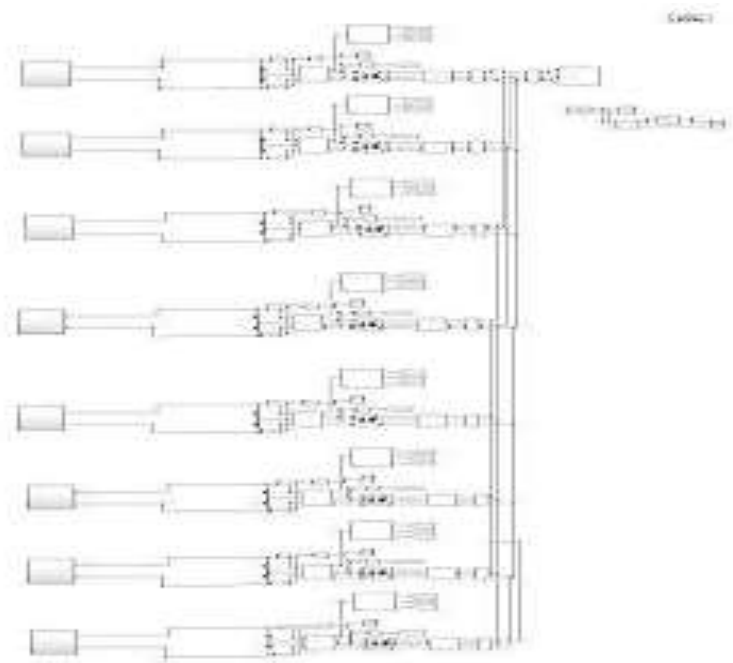

Fig.6Simulink model of $10 \mathrm{MW}$ solar PV grid connected power plant. 


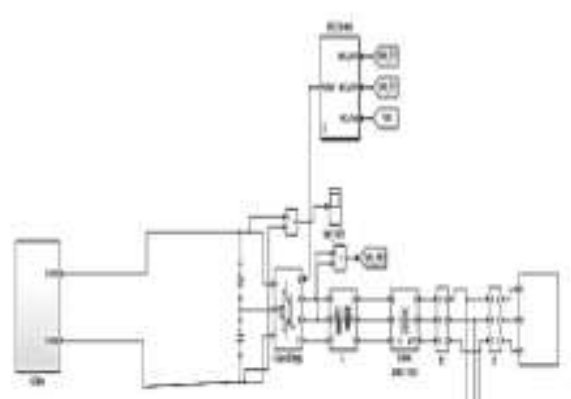

Fig.7Simulink model of single circuit of $1 \mathrm{MW}$ solar $\mathrm{PV}$ grid connected power plant.

\section{RESULTS AND DISCUSSIONS}

In this chapter we will discuss simulation results of the components design and the simulation of a photovoltaic power generation system using MATLAB and Simulink software. The simulation results of voltage waveform, current waveform, output power are presented.The simulations results of 10 MW solar PV grid connected power plant is shown below in Figures.

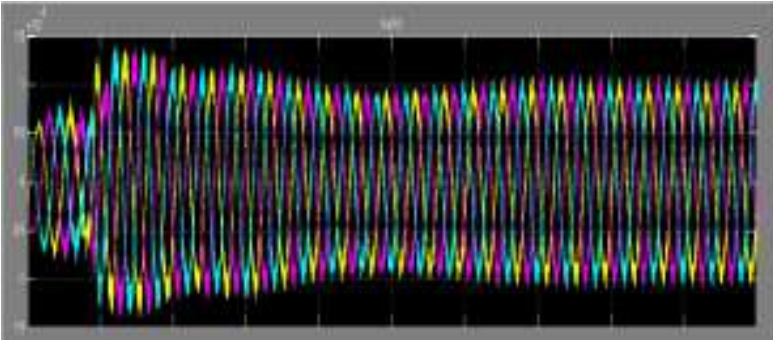

Fig.8 Voltage Waveform

A transformer is used to increase the voltage level to the voltage level of the grid and hence the power is supplied to the grid. The voltage generated is $11 \mathrm{kV}$ and it is same as the voltage generated by the proposed power plant.

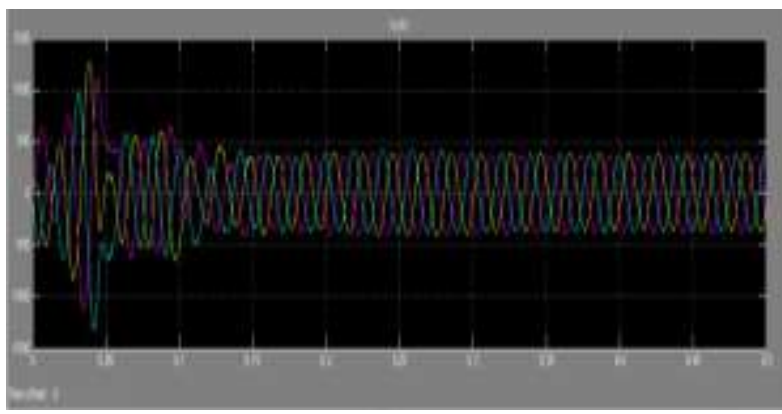

Fig.9Current Waveform

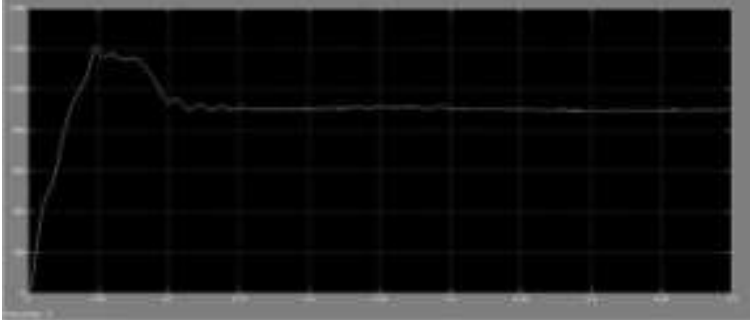

Fig.10Inverter Voltage Waveform

In order to supply this electrical energy to the grid this energy needs to be converted to A.C. For this task we use a inverter thus inverter helps in converting this D.C. supply into three phase A.C. It is observed that inverter permissible DC voltage is 900 $\mathrm{V}$ and the same is obtained.

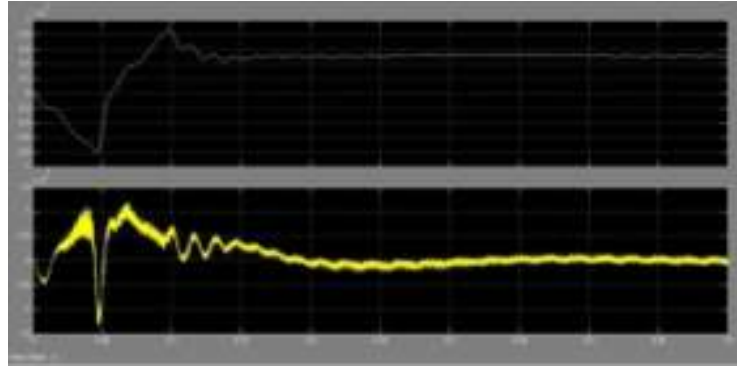

Fig.11Active and Reactive Power Waveform

It is observed that $10 \mathrm{MW}$ solar PV gridconnected power plant produces $9 \mathrm{MWp}$ power initially and later as the irradiation of sunlight it produces the power as shown in the below table. A special analysis tool was usedfrom the user graphic interface "PowerGUI". By using this instrument one can notice the waveforms of the phase voltages and currents at the output are depicted. The power produced is approximately $54000 \mathrm{kWh} /$ day and the generation of the proposed power plant is 50240 $\mathrm{kWh} / \mathrm{DAY}$. From generation details it is said that generation of the power is almost same as the solar power plant so therefore we can say that the PV generating system was designed properly.

\section{CONCLUSION}

The present paper deals with the simulation of the designed PV grid by using Simulink. The PV generation system behaves well in different conditions of solar radiance and temperature of PV panels, and extracting the maximum power from the PV panels owing to the MPPT technique. The study shows that the PV generation system is also providing a voltage, current, power same as the realtime power plant and it is compared with the simulation power plant.The generation of the power is almost same as the real-timessolar power plant so therefore the modeled design is found to be well suited for the PV generating system. 


\section{ACKNOWLEDGMENT}

The authors are thankful to Don Bosco Institute of Technology for providing necessary facilities \& support and Dr.H.Naganagouda, Director, National Training Centre for Solar Technology KPCL Bengaluru for providing the input data of the plant which was required for the above analysis.

\section{REFERENCES}

[1] B. Shiva Kumar, K. Sudhakar"Performance evaluation of $10 \mathrm{MW}$ grid connected solar photovoltaic power plant in India" www.elsevier.com/locate/egyr,Energy Reports 1 (2015) 184-192.

[2] Bharathkumar M, Dr. H V Byregowda"Performance Evaluation of 5MW Grid Connected Solar Photovoltaic Power Plant Established in Karnataka" International Journal of Innovative Research in Science,Engineering and Technology (An ISO 3297: 2007 Certified Organization) Vol. 3, Issue 6, June 2014.

[3] Ami Shukla, ManjuKhare, K N Shukla"Modeling and Simulation of Solar PV Module on MATLAB/Simulink" International Journal of Innovative Research in Science,Engineering and Technology (An ISO 3297: 2007 Certified Organization) Vol. 4, Issue 1, January 2015.

[4] CaishengWang,M. HashemNehrir,"Power Management of a Stand-Alone Wind/Photovoltaic/Fuel Cell Energy System" IEEE Transactions on energy conversion, Vol. 23, No. 3, September 2008.

[5] Eduard Bullich-Massague, RicardFerrer-SanJose, MònicaAragues-Penalba, Luis SerranoSalamanca, Carlos Pacheco-Navas, OriolGomisBellmunt"Power plant control in large-scale photovoltaic plants: design, implementation and validation in a 9.4 MWphotovoltaic plant" IET Renewable Power Generation Selected Papers from The Wind and Solar Integration Workshop 2014.

[6] Askari Mohammad Bagher, Mirzaei Mahmoud AbadiVahid, Mirhabibi Mohsen "Types of Solar Cells and Application" American Journal of Optics and Photonics. Vol. 3, No. 5, 2015, pp. 94-113. doi: 10.11648/j.ajop.20150305.17.

[7] P. Madhavi, Dr.J.Viswanatharao"PV Cell Fed Synchronous SEPIC Closed Loop Converter for BLDC Motor Drive Applications" International Journal of Scientific Engineering and Technology Research Volume.05, IssueNo.40, November-2016, Pages: 8218-8222.

[8] M.kaouane, A.Boukhelifa and A.Cheriti“'Design of a synchronous sepic DC-DC converter for a stand-alone photovoltaic system" proceeding of the IEEE $28^{\text {th }}$ Canadian conference on Electrical and computer engineering Halifax,Canada,may 3-6,2015.

[9] Manukumar D.M, Ganesha T, Mallikarjunayya C. Math "Performance and Evolution of Grid Connected To 5MW Solar Photovoltaic Plant in Shivanasamudra" International Journal of Research in Advent Technology, Vol.3, No.1, January 2015E-ISSN: 2321-9637.

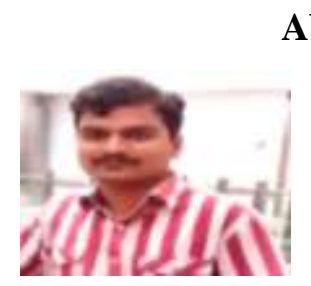

\section{AUTHORS}

Gururaj- Received B.E in Electrical and Electronics Engineering from DBIT, Bengaluru in the year 2015 and now currently pursuing M.Tech in Power System Engineering from DBIT, Bengaluru, Hisacademic interest area include power generation, Renewable Energy Sources, power electronics and power systems. E-mail address: gururajrawoor@gmail.com

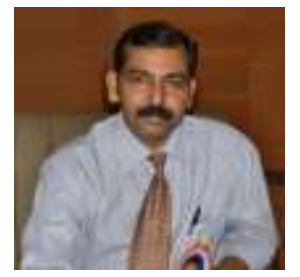

Anguraja R - Received B.E in Electrical and Electronics Engineering from Bharathidasan University in the year 1996 and M.Tech in High Voltage Engineering from SASTRA University in the year 2004.He is pursuing Ph.D. in High Voltage Engineering. He is currently working as Associate Professor \&Head of the Department in Don Bosco Institute of Technology. His research interests includes are Power System, Renewable Energy and High Voltage Engineering.

E-mail address:angurajaramasamy@gmail.com.

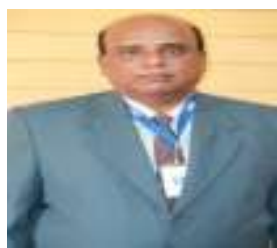

Prakash R -Received B.E in electrical and Electronics Engineering from Basaveshwara College of Engineering, Bagalkot, M.E in Power System Engineering from Walchand college of Engineering, Sangli and Ph.DfromVTU, Belgaum. $\mathrm{He}$ is currently working as a Professor \& Principal, Don Bosco Institute of Technology, Bengaluru. His research interest includes Power Systems, Renewable energy, Micro Grids \& Smart Grids.E-mail address: prakashrp1960@gmail.com 


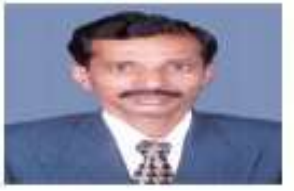

Dr. H. NAGANAGOUDA-

B.E., M.E., M.I.S.T.E., F.I.E.,

C.E., Ph.D.

He is currently working as Director, National training centre for Solar technology, Karnataka power corporation limited Bengaluru, Karnataka, India.

E-mail:hnaganagouda@gmail.com.

International Journal of Engineering Research and Applications (IJERA) is UGC approved Journal with Sl. No. 4525, Journal no. 47088.

Gururaj. " Comprehensive Approach of Modeling and Simulation of Solar Photovoltaic Power Plant." International Journal of Engineering Research and Applications (IJERA) 7.7 (2017): 06-11 